\title{
Studying A Portrait of the Artist as a Young Man through Heterogeneous Philosophy of Georges Bataille
}

\author{
Shataw Naseri (Corresponding author) \\ Faculty of Human Sciences, Shahid Beheshti University \\ PO box 1619914611, 11, Sepah Street, Tehran, Iran \\ E-mail: conceptsareconcepts@gmail.com \\ Kian Soheil \\ Faculty of Human Sciences, Shahid Beheshti University \\ Shahid Beheshti University, Evin Sq., Tabnak Street, Chamaran Highway, Tehran, Iran \\ E-mail:ks1348@yahoo.com
}

Received:18-04-2014

doi:10.7575/aiac.ijalel.v.3n.5p.261
Accepted:28-05-2014

Published: 01-09-2014

URL: http://dx.doi.org/10.7575/aiac.ijalel.v.3n.5p.261

\begin{abstract}
Georges Bataille believes that most of his contemporary discourses were spiritual and/or intellectual ones. They were, for him, vegetation-like discourses looking upward and underlining the role of head and thinking in their paradigms. $\mathrm{He}$, instead, introduced the notion of "base materialism" which highlights the role of the lower parts of the body; it is here that Bataille raises the notion of "Acéphale" who has beheaded himself with a dagger in his right hand, and thus has beheaded the ruling head of his own body as well as the heads of his surrounding social discourses. For George Bataille, humans are linguistic being entrapped forever in a language system. However, he believes that this system is full of fissures and that through transgressive moments one can experience these voids within language. Through transgression one can look directly in the abyss of language, though he/she cannot see the extremity of these voids and thus Bataille believes that one cannot reach any signified, and therefore, any Bataillean "Impossible." As one can witness, linguistic human being is entrapped within narratives of language system defining him in terms of cause and effect and their related items namely linear time and space. Georges Bataille believes that any heterogeneous element which crosses the defined taboos of the body of self and society at some transgressive moments is regarded as a "foreign body" and an "alterity." This foreign body, as he regards, at the instants of transgression experiences "sovereignty" which means that he is at the epic of being a "sovereign being," of course momentarily, because he at those moments has stepped upon any ruling borders and is bound with no taboo and thus is the "sovereign" of instants. The present study endeavors to analyze Stephen Dedalus in A Portrait of the Artist as a Young Man and his Bataillean experiences in terms of narrative and language. A Portrait will be concentrated in the light of the heterogeneous notions of Georges Bataille in order to investigate if one can consider Stephen Dedalus as a horizontal Bataillean character. This study attempts to trace Bataille's notion of language as an unsolvable maze in A Portrait; the maze which has entrapped human beings forever. It is here that his view of the linear narrative and its linear time and space, is raised and is analyzed through a Bataillian viewpoint.
\end{abstract}

Keywords: Impossible, narrative, Achephale, Obelisk, Stephan Dedalus

\section{Introduction}

\subsection{Georges Bataille's heterogeneous notions of language}

Georges Bataille believes that most of his contemporary discourses were spiritual and/or intellectual ones. They were, for him, vegetation-like discourses looking upward and underlining the role of head and thinking in their paradigms. He, instead, introduced the notion of "base materialism" which highlights the role of the lower parts of the body; it is here that he raises the notion of "Acéphale" who has beheaded himself with a dagger in his right hand, and thus has beheaded the ruling head of his own body as well as the heads of his surrounding social discourses. For Bataille, human being is a linguistic being entrapped forever in a language system. However, he believes that this system is full of fissures and that through transgressive moments one can experience these voids within language. Through transgression one can look directly in the abyss of language, though he/she cannot see the extremity of these voids and thus Bataille believes that one cannot reach any signified, and therefore, any Bataillean "Impossible." As one can witness, linguistic human being is entrapped within narratives of language system defining him in terms of cause and effect and their related items namely linear time and space. For Bataille, these narratives are like Obelisk statue which has been erected high but beneath which lies guillotine, the tool of violence. Thus underneath the systematic narratives lay the fissures of language which can be experienced momentarily at the "sovereign" instants. For Georges Bataille any heterogeneous element which crosses the defined taboos of the body of self and society at some transgressive moments is regarded as a 
"foreign body" and an "alterity." This foreign body, as he regards, at the instants of transgression experiences "sovereignty" which means that he is at the epic of being a "sovereign being," of course momentarily, because he at those moments has stepped upon any ruling borders and is bound with no taboo and thus is the "sovereign" of instants. This "sovereign" being is regarded as "alterity" and "foreign body" because he/she is an "other" and not someone belonged to the bordering discourse. He is moving toward a Bataillean "Impossible" in transgressing the taboos over and over; it is "Impossible" because reaching the state of an absolute "autonomous being" is illusory in this language system which has entrapped the human being forever. However, Bataille believes that the Bataillean "sovereign" being must get closer and closer to this Impossible. The present study endeavors to analyze Stephen Dedalus in $A$ Portrait of the Artist as a Young Man and his Bataillean experiences in terms of narrative and language. James Joyce is an influential writer of the twentieth century. About his books Ulysses and Finnegan's Wake, Jacques Derrida states how Joyce was present in his first book, The Introduction to Husserl's Origin of Geometry (1962), and is present again in his key essay, "Plato's Pharmacy" (1968). Derrida's confession proves that besides being a fundamental influence in literature, Joyce is also an inspiration for the new ideas, and there are few philosophers or writers in the twentieth century who have not been influenced by him.

His work, A Portrait which this thesis is to focus on, is a nearly complete rewrite of his abandoned novel, Stephen Hero. A Portrait is the dramatic scene of its main character Stephen Dedalus whose mind and actions, in the present study, will be concentrated in the light of the heterogeneous notions of Georges Bataille in order to investigate if one can consider Stephen Dedalus as a horizontal Bataillean character. Stephen Dedalus, who is living in a strict Catholic setting, experiences some banned taboos such as eroticism for several times, which in turn leads him to do some other acts which are prohibited strictly in Christianity. The endeavor of the present research, as mentioned, is to investigate whether his adventurous affairs in his mind as well as in his deeds have the potentiality to be called the Bataillean horizontal acts.

This study attempts to trace Bataille's notion of language as an unsolvable maze in A Portrait; the maze which has entrapped human beings forever. It is here that his view of the linear narrative and its linear time and space, is raised. Bataille claims that this narrative can be fissured at the miraculous moments of transgression. For him, these moments prove that human being is not moving upon a fixed line with a fixed signified but is moving in a labyrinth, the labyrinth whose voids can never be filled. Stephen transgresses language at the moments of breaking the taboos; he through his transgressions tries to fill the voids of his linguistic being as well as narrative and is moving toward Bataille's "Impossible." However, Language is relative and slippery and is full of voids. These voids can never be filled completely and reaching a stable and fix signified is impossible. Stephen is moving toward this "Impossible" but he can never reach any fix signified. He is entrapped within this full-of-abyss language and its endless play of signifiers forever.

In this book, Stephen transgresses the religious Catholic discourse over and over. His transgressions are simultaneously transgressions against language and narrative system. He is experiencing some of the voids of these systems which look upward; however, beneath these systems there exist endless and eternal voids and abysses. They are slippery structures with no stable basis. Stephen as a linguistic being is entrapped within these linguistic systems and their concomitant linear time and place. He experiences some of these gaps by transgressing the taboos imposed upon his linguistic being; however language has embraced this being forever and his state of being an "autonomous being" and reaching the "Impossible" is impossible.

\section{James Joyce and Transgression of Language}

James Joyce, like Georges Bataille, in his writings pays attention to language and linguistic narratives. He believes that being and language are dissolved within each other and that these two phenomena cannot be separated from each other: "[f]or Joyce ... consciousness itself is all but identified with language and both consciousness and language develop through interactive processes" (Kershner 888). For him, language like a halo embraces the whole being through its signifiers as well as narratives. Joyce has a fundamental distrust of language, and he is the least narrative of novelists and regards narrative as Achille's heel of fiction; therefore, in his works he attempts to overturn the authority of narrative and also to abolish time.

One of the most significant narratives against which Joyce battles in his novels is the narrative of history, a linear progressive story of change and development. He believes that history is a project in which something happens and produces result. His characters have the "terror of history- as a mere succession of events happening in historical, profane, and linear or irreversible time" (Cronin 435). For Joyce, history is a linear narrative which has a beginning, a middle point, and an ending; it is what Bataille calls a "project" which, as noted in chapter two, produces a utilitarian ending, a result. History is not an end in itself, and it is valued as long as it has some utility. In history the moments are not validated but the linear developing progress, with the succession of events, which is moving forward with the conduction of cause and effect. Joyce also observes Christianity as a linear narrative which began with the birth of Christ and ends with Doomsday, and which is determined by the will of God. A. M. Klein defines the history of Christianity "as progress, development, teleology, the self-realization of Spirit, the revelation of God's will in time- that 'One far-off divine event, / To which the whole creation moves'" (qtd. In Spoo 18). God, for Joyce, is a transcendental signified and a big idea, from which all the narratives must be liberated. Indeed, the removal of this Head-Center from the Christian narrative as well as any other narrative means the liberation of the irruptive energies of language. In his writings Joyce and Bataille try to liberate their characters from the governing rule of this Center, and thus to release them from being a defined signified. These characters are to become oozing and fluid signifiers which through 
transgressing the ruling structure as well as through creating the Bataillean and horizontal instants disrupt the defined syntactic and semantic linguistic systems and thus their own illusory fix signified.

In order to liberate the text from the net of language and narrative Joyce sets "the language of text free to bear often contradictory meanings" (Foster 143). The presence of contradictory meanings as well as paradoxical occurrences throughout the text liberates it from the linearity of narrative as well as the linearity of time and place. The true purpose of these contradictory meanings and events is never detected and, therefore, their true utility and result is never known, and this lack of utility is what Georges Bataille appraises. Joyce's aim is also to release the rhythms because "[f]or Joyce the process of achieving the 'simplest liberation of rhythms' also liberated the artist, for better or worse, from the idols of the marketplace; the act of expressing the self freely and fully in ... periodic prose was analogous to more active, political forms of resistance" (Spoo 5).

The liberation of rhythm by the artist is liberation from the strict and structural narrative system as well as the utilitarian discourse of the market, because when rhythm is frozen by the grammatical syntax within the narrative, the flow of the text is completely linear and, thus one can perceive its progressive movement toward an end. However, the existence of periodic prose as well as fluctuating rhythm implies the existence of circulation in the text, which endangers the linearity of the utilitarian narratives. Joyce believes that the artist through his potentiality to manipulate the system of language has the ability to resist the dominant linguistic discourses as well as to subvert the authority of time and history. His character Stephen Dedalus in his novel A Portrait is an artist who attempts to transgress the linguistic system. This attempt to riot against language will be investigated in detail in the following section of the present study.

\section{A Portrait and Transgression of Narrative and Language}

In Joyce's novel A Portrait the dominance of narrative is perceivable from the very beginning since the first page of the novel begins with a narrative told by his father. In the opening of this novel one hears the voice of the father which is also the opening of narrative: "[o]nce upon a time and a very good time it was there was a moocow coming down along the road and this moocow that was coming down along the road met a nicens little boy named baby tuckoo..../ His father told him that story: his father looked at him through a glass: he had a hairy face" (Joyce 7). Stephen from the very childhood, when he is a "baby tuckoo," finds himself inscribed in a story; he is entrapped in the linguistic narrative from the very beginning of his life, and thus from the very beginning the dominance of linear time, linear place, and linear narrative is conceivable. This story has a progressive movement toward an end, and here is observed no periodic or circular repetition. This developing narrative is linear in time and place; it is a progressive movement with a beginning, middle, and an end: it is like "[w] hen you wet the bed first it is warm then it gets cold," with the conduction of a causeand-effect movement.

Stephen himself from the very childhood is obsessed with language. In the playground of the school he sees the ball of the footballers as a "greasy leather orb flew like a heavy bird through the grey light" (8); he decorates some words with his own would-be-artistic imagination. He is also very sensitive to the sounds of the words, and finds in them experiences that sheds light on their dictionary meanings, and thus enriches them with his own imagination. When a boy at Clongowes is called the perfect's "suck," Stephen thinks that "suck was a queer word ... but the sound was ugly" (11). He ponders that once with his father in a hotel the dirty water had went down through the hole in the basin and that this occurrence had made a sound like suck; later on he ponders on the sound of "kiss" when his mother kisses him before going to bed. Stephen listens very carefully to his elders talking about politics and the current situation of Ireland and the "[w]ords which he did not understand he said over and over to himself till he had learned them by heart." He also deforms the "wild rose blossoms" (7) song and composes a new song which is "his song" (7). He ponders upon his own name and God's name, which seem to have no holy meaning for him: "God was God's name just as his name was Stephen, Dieu was the French for God and that was God's name too" (16). Stephen repeats the strange phrases in his mind over and over, and replaces them in different contexts and conjugates them recurrently: "was that a sin for Father Arnall to be in a wax or was he allowed to get into a wax when the boys were idle because that made them study better or was he only letting on to be in a wax?" (48) He also wonders how the word "rose" can have pink and cream colors and that finally if one can have a "green rose" (9).

Stephen, as mentioned in chapter three of this study, has grown up within the discourse of Catholicism and before his restless wanderings in some infamous regions of Dublin and particularly his excessive erotic consumptions at the ending of the second chapter as well as the beginning of the third chapter of the novel, his language is full of religious lexicons and his mind is bound to Christian language. The words "God," "chapel," "Lord," "Father Minister," "Brother Michael," "bishops," "Tower of Ivory" frequent Stephen's mind over and over. The language of his mind has a religious veil which secures his psyche from any obscene or vulgar item. Stephen before his savage wanderings is so innocent that when he is teased by his fellow students for having kissed his mother at home, he does not know whether or not it is good to say he kisses her mother. However, when the unrests start in him and cause him to roam in the dark alleys at nights, the nature of his language alters. It is here that the language of his mind becomes ambiguous, and thus some gaps emerge in his language, and the exactness of the religious items of his mind disappears.

Stephen does not know the nature of his restlessness in the second chapter; he does not know the purpose of his wanderings. A "vague dissatisfaction" (67) grows up within him, whose reason and nature he cannot perceive, and he witnesses an "incommunicable emotion" (75) within himself indistinguishable and inexact. He thinks that he is seeking for someone who eludes and evades him, but he does not know who this someone is. The existence of the word "someone" in his lexicon in this period of his life implies the existence of vagueness and ambiguity within the linguistic structure of his mind. The word "impulse," too, recurs again and again in his mind; a word which denies the presence of 
linearity within the narrative of his psyche, because these impulses occur unintentionally and without any conscious plan, and this opposes the linear cause-and-effect process of narrative. Here he feels himself "a gloomy figure" (68), implying an ambiguous figure with no light and clear character.

Entrapped within his wandering restlessness Stephen's lexicon has become mobile and fluid, and it exits from its former solid and immobile religious nature. Here, one can observe the words "dance," "wandering," "breeze," "impatient movement," "the stream of moody emotions," "tide," "haste," "vapours," "water" and some other fluid words which cannot be imprisoned within their dictionary meanings as well as the narrative framework of Stephen's mind. His language has started to ooze, it is not fix any more, but is trickling within the narrative. It is also here that some rupturing words which can disrupt the whole narrative appear in his mind; the phrases such as "fierce longings," "savage desire," "secret riots," "brutish joy," "orgiastic riots," "wasting fires of lust," "luxury," "unrest," "revolt," can be observed in the dramatic scene of his mind. These are the Bataillean horizontal phrases which put the vertical narrative in serious hazard. These phrases carry with themselves a kind of abrupt and impulsive energy which can rupture any grammatical syntax. Here one witnesses that Stephen's lexicon has transfigured from the religious as well as divine nature to bodily and erotic one.

As noted, Stephen's language has started trickling in his restless and brutal wanderings. He is walking in the darkness of night in the obscure locations of the city, and thus he is dissolving and abolishing linear time, place, and the narrative. Darkness is the source of ambiguity, unknown, as well as Bataillean appreciated obscenity, and it dissolves any linearity and clarity; nothing is light and illuminated in darkness. Darkness in itself is replete with voids and vague gaps which can never be filled by any vertical Hegelian, religious, or narrative systems. Darkness is the suitable space of Bataille's "secrecy" to commit any transgression against any structure. Indeed, these pages of the novel which depict Stephen's brutish and luxurious wanderings in the unknown darkness are among the most ambiguous parts of the book. It is here that beside Stephen's verbal language the narrative, too, has started oozing simultaneously with his linguistic being which has already started oozing. However, the principal dissolution of the self, language, and narrative is at the moment of his transgression of the erotic taboo, and thus the barriers of self and narrative. This subject will be investigated in detail in the following parts.

On the brink of transgressing the strictly prohibited sexual taboo Stephen's desire to encounter prostitutes is repeated so intensively that his mind wears the garment of physicalized language, and has left his religious lexicon totally: "[h]e felt some dark presence moving irresistibly upon him from the darkness, a presence subtle and murmurous as a flood filling him wholly with itself. Its murmur besieged his ears like the murmur of some multitude in sleep; its subtle streams penetrated his being" (100). This dark presence is language which is murmuring vaguely. The murmuring of language means its lack of any bright order and exactitude. When something or someone is murmuring one cannot have any exact interpretation; it can have any meaning and at the same time no meaning. Murmuring is full of the unknown and ellipsis which remain mysterious and uudecoded forever; it is like a flea which annoys the precise linguistic system. Bataille's language is also murmuring within the systematic narrative. Therefore, it has the potentiality to dissolve, what he calls, the "project" of language. Bataille is against the utilitarian "political economy" which overshadows the narrative system. He throughout his whole oeuvre tries to release the "general economy" of language. Murmuring is an attempt to liberate the non-utilitarian and luxurious "solar" energies of language, and to exit it from the economical projects.

In A Portrait simultaneously with the murmuring of language there exists the murmuring of narrative; narrative here is full of ambiguous and dark voids and it lacks any linearity. Vague speech or murmuring is free from syntactical and grammatical restraints and it breaks the linearity of signifying chain. Stephen's physicalized language is so fundamental for him that even in the third chapter of the novel when he is in his religious phase, it flows in his mind. Here when he is tolerating a strict religious period "[h]is sins trickled from his lips, one by one, trickled in shameful drops from his soul festering and oozing like a sore, a squalid stream of vice" (144), which is a physicalized language. In this phase, also, his description of the goatish creatures of his horrible vision is through physicalized language: "from their lips issued soft language," which is, in fact, the murmuring of language.

This physicalized language is more dominant when Stephen is in the prostitute's room: "[t]ears of joy and relief shone in his delighted eyes and his lips parted though they would not speak," and that "[h]is lips would not bend to kiss her. He wanted to be held firmly in her arms, to be caressed slowly, slowly, slowly," and

[w]ith a sudden movement she bowed his head and joined her lips to his and he read the meaning of her movements in her frank uplifted eyes. It was too much for him. He closed his eyes, surrendering himself to her, body and mind, conscious of nothing in the world but the dark pressure of her softly parting lips. They pressed upon his brain as upon his lips as though they were the vehicle of a vague speech; and between them he felt an unknown and timid pressure, darker than the swoon of sin, softer than sound or odour. (101)

Through transgression against the erotic taboo at this Bataillean "miraculous moment" he also commits transgression against the taboo of language. Here there exists the "diffusion of the self within the context of Stephen's sexual crisis" (Jacabos 21). Stephen's linguistic being and the narrative of his psyche have been dissolved at this, what Bataille calls, "consumptive" moment. Stephen removes the capitalistic useful communication of linear narrative at this instant. He is a Bataillean Acéphalic figure who holds a dagger in his right hand and sacrifices language and the linear time and place; 
he is "conscious of nothing" at the moment of his transgressing this rooted erotic taboo and at the same time his traumatic transgressing the language taboo. Stephen is very close to Bataille's appreciated state of being "sovereign" since nothing rules him at this close-to-"summit" moment.

Stephen repeats his erotic orgies over and over in the first pages of the third chapter of the novel, and thus puts dagger into the body of language recurrently. This "Stephen's unsettling multiplicity of language and sexuality" (22) is what the Bataillean Acéphalic figure Gilles de Rais does in sacrificing and beheading narrative-the-head of his own being repeatedly. De Rais, as mentioned in the second chapter of this thesis, committed recurrent sadistic crossing the sexual taboo and the language and narrative system. (Gilles de Rais's transgressions are more violent, though). He performed sadistic and sexual abuse against children and then murdered them in a sadistic way because he wanted to see death at work. He wished to experience the limits of Bataillean "Impossible." Death is a violent "Impossible" which the Hegelian system tries to assimilate within itself. Stephen's transgressive deeds are, indeed, the conscious acts of powerful violence against being and language and moving toward experience the limits.

\subsection{Stephen, Bataillean "Anguish" and Language}

Stephen Dedalus in his erotic instants removes his linguistic being; however, when he experiences his Bataillean "anguish" due to his transgressing the fix root erotic taboo, he, as mentioned in the third chapter of the present study, converts to divine cult from obscene and earthly joys. He takes part in all the religious ceremonies and is such an obedient Catholic subject that he is proposed priesthood vocation. As noted earlier, the source of Stephen's anguish and thus his conversion to divine cult is Father Arnall's torturing preachment. This religious speech is the embodiment of a strict linear narrative as well as linear time and place. There exists no ambiguity or sudden moments in this speech; it is an exact and clear story and the words do not have any multiple or vague meanings. Their meanings are the dictionary meanings. Here, there are no murmurings, darkness, silence, or ellipsis which dissolves the time and language. It is in this chapter of the novel that there are limits to Stephen's revivalist language due to the weighty and quite rigid syntactical Catholic system of thought presented to him by Father Arnall's speech, which is full of religious images and language. Andrew Gibson in his book James Joyce claims that Father "Arnall's language, his rhetoric and imagery are vulgarly late Victorian. They draw repeatedly on Victorian middle brow, commercial, popular-cultural and popularscientific registers" (105). He maintains that in this chapter of $A$ Portrait Stephen's "[o]bedience to the Church breeds order, discipline and exactitude (including exactitude of language)" (105). He has a kind of discipline in his life even in his mind. The exactitude of narrative of his mind is obvious in this phase of his life. Indeed, as Bataille claims, the vertical and disciplinary systems impose exactitude and order on their subjects, and eliminate any element which lacks this exactitude, and which is vague and hazardous in the structure. Regarding this matter, one can point to the phenomenon of death which is rupturing and disruptive within any "project"-based system and which annoys any utilitarian linearity of cause and effect. Bataille asserts that vertical systems such as Hegelian system as well as Christianity bring the irruptive and impulsive death into their structures and attempt to interpret it according to their own logic. They will impose their order upon any obscene entity and will dissolve it within their own paradigms. This is what one observes in Father Arnall's religious speech where he, as a representative of the Irish Catholic Church, describes death and the after-death world in detail as if it is part of the project in which he himself has been defined.

Influenced by this torturing preachment, Stephen is attracted to religion again and his artistic yearnings are almost repressed during this phase of intensive religious experience. Here, only one word fascinates him and it is "God," a Bataillean "Obelisk," which he sees everywhere because all is God for him: "All, God! All, all!" (Joyce 126). The word "God" is a transcendental idea and signified which conceals any violence beneath itself; it is an "Obelisk" which depresses any irruptive volcano underneath. This word is the unshakable ideal of language of the Irish Catholic Church, and the Irish people are circling around and around the center of this divine ideal concept. Stephen, too, just ponders upon this transcendental signified. The sound and the existence of no other sound are important for him as he deprives his own ears of hearing any other sound. During this religious crisis his relationship with the Church is fundamentally linguistic and mostly it is its liturgical language which has basically absorbed him. Even when he is tempted to join the vocation of priesthood, he is curious about the language and the definitions common in linguistic system of the Church: "[h]e would know then what was the sin of Simon Magus and what the sin against the Holy Ghost..." (159).

\subsection{Repetition and Transgression of Language}

As mentioned earlier in this study, A Portrait is the dramatic scene of Stephen's mind. Stephen in the novel is, in fact, struggling against the narrative of his own psyche because, as Bataille claims, human being is a linguistic being. One can claim that before the beginning of his wild wanderings in the obscene districts of Dublin led to those erotic transgressive instants, Stephen's wrestling against the narrative structure of his psyche is not fully conscious; however, these struggles are crucial because they occur in Stephen who is a would-be-artist, and who later commits transgression consciously. One way to shatter or at least to endanger the linearity of the utilitarian time and narrative is repetition. Mircea Eliade, the Romanian historian, asserts that repetition is "an implicit abolition of profane time" (qtd. In Cronin 438); he believes that repetition confers a "cyclic direction upon time" (438), because in this case "[e]verything begins over again and its commencement every instant. The past is but a prefiguration of the future, no event is irreversible and no transformation is final" (438).

For Georges Bataille, too, repetition is a vital phenomenon; his novels are full of repetition. The events and the sentences are repeated over and over and the signifiers circulate again and again not around their own non-existent and illusory signified neither around a transcendental signified such as God, but around themselves. It is this circulatory recurrence which puts them in an endless play of signifiers. These novels emphasize repetition and not a continuous and 
chronological development. As an example, in his novel Story of the Eye, as noted in chapter two, the repetition of the eye is dominant. In each scene the serialized presence of the eye with different variations is perceivable, and it is in this way that it escapes any fix signified and interpretation. The signifier of eye circulates around itself over and over without having any dictionary meaning. This recurrent eye is the embodiment of Bataille's own Critical Dictionary in which all the common signifieds of the signifiers are collapsed forever, and their everlasting participation in, what he himself calls, the "jeu" of signifiers remove any garment of identity from their bodies. This eye-signifier is a Bataillean "nude" and heterogeneous element, a "waste matter" which the linear narrative attempts to either assimilate it within itself or excrement it like the waste matter eliminated from the body.

Stephen's mind is the scene of the repetition and recurrence of some phrases and words as well as some scenes before his crossing of the erotic taboo. As an example, at the Christmas dinner he mediates on Eileen's hand and this mediation occurs again in his mind when he is returning to Clongowes: "Eileen had long white hands. On one evening when playing tig she had put her hands over his eyes: long and white and thin and cold and soft. That was ivory: a cold thing. That was the meaning of Tower of Ivory" (36). Christianity is a linear narrative beginning of which is the birth of Christ and its last event is Doomsday. It validates no heterological repetition which puts its defined and utilitarian "project" in hazard. Thus, although in this cult there are the cyclical repetitions of the liturgical year, because the main linear narrative is preserved, Stephen finds no relief and consolation in this liturgical repetition. He is exhausted of this irreversible flow of time in whose cage everything has a beginning, middle, and an end. He tries to release some nondefined rupturing elements by committing perverse sexuality.

After and before Stephen's erotic transgression the number of the cyclic repetitions of some phrases in his mind putting in hazard the whole narrative of his psyche with its defined linear time and place is increased strikingly. On the brink of his crossing the erotic taboo there exist the words "lust," "darkness," and "revolt," in his lexicon and they are echoed over and over in the next parts of the novel. After his erotic transgression at the ending of the second chapter of the novel, one witnesses the repetition of some phrases; the words "sudden," "desire," "excess," "instant," and "wild" are repeated at the beginning of the third chapter, where the reader can witness Stephen's luxurious erotic orgies many times. These words are repeated later in the fourth chapter of the novel, when the unrest of doubt emerges again in him; they are also repeated before and after his epiphany at the beach.

After his experience of erotic limit, as noted in the third chapter, Stephen is inflicted with a Bataillean "anguish" leading to his experience of a full-of-horror epiphany moment. The repeated "hither and thither" of the movements of the goatish beings in this epiphany moment conveys the indistinctness of speech and this phrase is repeated later in the climactic scene of the girl at the beach in chapter four. There, when the girl becomes aware of the presence of Stephen, she gently stirs the water with her foot "hither and thither" (Joyce 172): "[t]he first faint noise of moving water broke the silence, low and faint and whispering, faint as the bells of sleep; hither and thither; hither and thither" (172). Here one hears the murmuring of the girl's gently stirring the water which is, indeed, a murmuring invitation to sexuality. In this scene, one of the most vital and fresh moments of the novel, one witnesses again the interconnection of language and sexuality. At this sensual moment the repetitive murmuring of language is heard, again implying the lack of exactitude of language and also the murmuring as well as the dissolution of narrative. Here the repetition of the words "alone," "waste," and "tangled" recalls some moments of chapter two and three. He is alone and near to" the wild heart of life"; "alone," "amid" and the "waste of wild air" have been echoed throughout the last pages of the second chapter and the first pages of the third chapter of the novel. At these instants although the tone is elegiac and the language flows like the evening sea breeze, with this mild fluid breeze one can feel, too, the slapping against language and narrative.

Hayman believes that the randomness of stream of consciousness is paratactic and heterogeneous and it is not rationalized by syntactic patterns but is a random thought with no rule and no defining taboo; he claims that in $A$ Portrait the ambiguous slippage between the third person and the first person in the diaries is an ambiguity that may be a signal of stream of consciousness. David Hayman believes that Stephen's diary is a radical micro-parataxis because it reveals a "disembodied thought" (158) and they do not move forward but backward, and that in these diaries one can see a circulation which, in fact, embodies the circulation of the whole novel. As Levenson affirms "[t]he diary abounds with echoes of earlier passages, repetitions of key words, puns, verbal substitutions. Long sequences from the earlier narrative reappear in a form of symbolic notion" (1026).In this diary "strange cases advance from a cave. They are not as tall as men, one does not seem to stand quite apart from another, their faces are phosphorescent, with darker streaks. They appear at me and their eyes seem to ask me something. They do not speak" (Joyce 250). This reminds us of Stephen's horror-full vision after he listened to Father Arnall's speech.

In A Portrait one also observes the recurrence of the word "dung" in Stephen's mind throughout the novel. This word recalls "the filthy cow yard of Stradbrook with its full green puddles and clots of liquid dung" (63) in chapter two, and "this stinking dunghill of a world" (241), and the "cake of cowdung" that Lynch once ate (206) in chapter five. Dung is excrement, a Bataillean "base material," repeated in Stephen's shapeless thoughts over and over. It conveys, what Georges Bataille calls, the "accursed domain" of Stephen's psyche; the domain which is obsessed with the lower part of the body. Equally one witnesses the "swishing tails" of the goatish creatures echoed in the "swish of the sleeve of the soutane" of Father Dolan (50); the "[s]oft language issued from their spittleless lips" (138) is echoed in Father Arnall's voice which is "gentle and soft" (52). The creatures' "hard eyes" correspond to the rectors' "dark and stern eyes" (108) and also "their old bony faces" (138) is echoed later on in Stephen's mind when he has a depiction of Heron whose "forehead was narrow and bony" (76). Too, the "malice" of the goatish creatures echoes in the "rule malice" of Stephen's professors. Beside all these repetitions, the fact of the repetition of Stephen's committing eroticism for many 
times after his first sexual affair with the prostitute in the last page of the second chapter is the best testimony for repetitive breaking the linearity of time and narrative. These orgiastic repetitions remind one of the erotic repetitions of the characters of Bataille's novel Story of the Eye and Gilles de Rais, of course not with that much intensity, through which they were shattering momentarily the coherence and the order of the narrative.

A Portrait does not have a full closure, and thus it does not have a final statement. The lack of closure in this novel conveys the impossibility of imposing finality on Stephen's contingencies and infinity. Michael Levenson claims that Stephen throughout the whole novel is worried over endings; even when he is a child, he wonders where the universe ends. When he is discussing with his friend Cranely, he is again worried over the end of their conversation: "Stephen, struck by [Cranely's] tone of closure, reopened the discussion at once" (243). Levenson continues that Stephen's refusal of closure is echoed in his "succession of his rebellions" (1020) which, in turn, can be regarded as his attempts to avoid closed forms. He continues that "[t]he proud cry of the aspiring artist, 'on and on and on and on!' is a demand for a perpetual [and repetitive] crossing of limits, resolute march to the end of the universe." (1020). According to him, $A$ Portrait does not have a leading movement and pattern toward an end, but is a recurrence and repetition of identities and similarities through which Stephen challenges finality; it is a repetition of Stephen's juxtapositionory attractions and declines and also of similar sentences with minor variations in Stephen's acts as well as his mind. Therefore, Levenson believes that $A$ Portrait is not a bildungsroman with a developing pattern and with an end as its finality.

\subsection{Epiphany and Transgression of Narrative}

Another factor which plays an important role in breaking the narrative structure of Stephen Dedalus's being is his experiencing epiphany moments. Epiphany is, in fact, one of Joyce's most significant steps to fulfill his purpose of validating the non-linear moments. Epiphany is a non-narrative phenomenon which occurs for his characters in some instants shattering the whole linear project of their lives. It is "a sudden heightened awareness, a moment of revelation" which is discontinuous with the rest of narrative- with its linearity of time and space; the narrative "which is a fixed sequence of what-came-before and what-came-after" (Helming 91). Epiphany is the instant of contingency; it is the transcendence of moments. Epiphany according to Jacobos is a "sudden and thus singular spiritual manifestation" (23); it runs up against the limits of language, since they freeze some vital and impulsive moments forever (freezing epiphany); they are "[i]ntrusion upon the established frame of the narrative" (Benstock 710). Epiphany is least narrative; it is an accidental obliteration of time and thus of place. It abolishes one's common experience of time as continuous duration and removes the scientific definition of time as a "homogeneous [and linear] succession of measurable intervals" (Beplate 300). It breaks the "[c]hronological continuum -yesterday, today, and tomorrow" (Benstock 716). Stephen Dedalus experiences some plurality of epiphany moments; the moments which are the rupturing and the heterogeneous moments within the homogeneous time. It is at these mystical moments bound with chance, what Bataille praises so much in his notions, that he puts aside the veil of Catholic ideal verbal habits.

Bataille, too, praises the mystical and visionary moments. His novels are full of these instants which, as Kierkegard claims, are the synthesis of eternity and temporality. For him, these headless moments are the volcanic instants beneath narrative-the-Obelisk. They sacrifice and liquefy the slippery system of language. Although these epiphanic and visionary instants do not carry so much violence upon their own shoulders like the violent moments of transgressing taboos, they are, what Bataille calls, some points of blindness within the defined narrative system. The points which are the unsolvable voids in the too much illuminating and homogenizing systems.

In A Portrait "there are large temporal leaps" because "the emphasis is on the signifying, shaping, and reflecting functions of small moments as opposed to 'events' in a continuum" (Hayman 157). At any such heterogeneous moments (epiphany belongs to these heterogeneous moments) the duration of linear time is interrupted and we witness that the narrative structure with its sequence of events is also disrupted. Therefore, the text in this novel is not "an organic, unified, self-identical whole, but as an always-breached contract, a narrative with an irreducible gap" (Thomas 284). Attridge claims that the mythical moments of Stephen challenge the limits of narrative and language; due to this reason the novel has a discontinuous narrative. In A Portrait the narrative continuity is abandoned in order to make some transcendental moments that are separated from the time contiguous in the narration.

Some vital heterogeneous epiphanies occur for Stephen after his transgression of the erotic boundary as well as of his own linguistic being. While he is regretting having crossed the defined sexual taboo and is bearing an intensive Bataillean anxiety in chapter three, he has an epiphany as he enters his room and there he has some vision of some goatish figures whose eyes are full of malice. His other epiphany takes place when he has recently quitted his religious phase, and he has also rejected the priestly vocation that has been offered to him by the Jesuits, and is ready and ripe for a new baptism. This new baptism occurs at the beach, as mentioned earlier, when he experiences the bird-girl epiphany, a lyrical epiphany and a timeless void. It is in experiencing this earthly epiphany that he steps into the world of senses again. This scene of horizontality reveals the extraordinary nature of trivial scenes. The scene of seeing a girl is quite an ordinary view for a common observer and it is usually taken for granted; however, for Stephen Dedalus it is not ordinary, but is an inspiring horizontal moment which revolutionizes his whole vertical life.

This epiphany is very crucial regarding the fact that during his piteous and religious phase Stephen was only circling around the big word of Christianity- God- which, as noted, is an ideal word. From this girl-bird epiphany instant onward it is not this ideal word which occupies Stephen's psyche but the earthly and peripheral subjects. The veil of the ideal language and of the platonic concepts, put upon his face earlier by the discourses surrounding him, is put away here and the tiny but eternal momentous beauties of this world are revealed to him; the mortal beauties which are miraculous not due to their reflection of some vertical and transcendental world, or to their being the sources of capitalistic utility, but 
simply because they are. His spontaneous composition of the villanelle is also a culminated epiphany moment which exceeds and transgresses his previously expressed aesthetic theories as in his theories he rejects any "kinetic" texts but his own villanelle has a "kinetic" and sexual nature. It is these chance-based instants which Bataille appreciates so much since these miraculous moments are full of energy beneath Obelisk of narrative, sacrificing and beheading its head, at least momentarily.

\subsection{Paradox, Juxtaposition and Transgression of Narrative}

A Portrait is full of paradoxical and juxtapositionary scenes and elements. This is because the novel, as noted earlier, is the stage drama of Stephen's psyche, and it is his psych which is full of paradoxes. Throughout the whole book Stephen's mind is infected with alternative imagination and reality; his moments of having an imaginary thought is immediately followed by reality. In chapter one the reader can observe such paradoxes; as an example, when Stephen and his fellow students go out of the hall in order to go to the chapel to say the night prayers, he is thinking about the color of the marbles and that their color is like the color of sea at night and that " $[\mathrm{t}]$ he sea was cold day and night: but it was colder at night. It was cold and dark under the seawall beside his father's house. But the kettle would be on the hob to make punch" (Joyce 17), then immediately we hear in his mind the echo of the perfect of the chapel praying, a real scene. Again in the same chapter one observes Stephen thinking about the cyclical pattern of the vacations and the terms: "[f]irst came the vacation and then the next term and then vacation again and then again another term and then again the vacation. It was like a train going in and out of tunnels and that was like the noise of the boys eating in the refectory when you opened and closed the flaps of the ears. Term, vacation; tunnel, out; noise, stop" (17). These imaginative thoughts are followed straight away with his real decision to pray in the chapel and then to go to bed. These are just two examples of his paradoxical mind in the first chapter. The following paragraphs elaborate the other juxtapositions present in his psyche.

After Stephen's crossing the erotic taboo for many times in chapters two and three these paradoxical alternatives become more prominent. In chapter three when he is experiencing that terrible vision of some creatures with "murmuring faces" as well as "murmurous voices" (136), this vision alternates immediately by his awareness of his own room. In the same chapter he experiences another horror-full vision of some "[g]oatish creatures with human faces, hornybrowed, lightly bearded and grey as indiarubber" (138) followed directly by his flinging the blankets from his head and going out of the bed, which is a real scene. In chapter four his epiphany of his mythological artist father alternates immediately with the real scene of his ecstatic breath and cry. Also in this chapter Stephan's epiphany moment of the girl-bird at the beach is followed on the spot with the realistic scene of his turning away from her and running toward the shore. After this experience of the beach, he falls asleep, and he imagines the merging of two realms in his image of the moon imbedded in the earth: "[h] climbed to the crest of the sandhill and gazed about him. Evening had fallen. A rim of the young moon cleft the pale waste of the sky like the rim of a silver hoop embedded in grey sand; and the tide was flowing in fast to the land with a low whisper of her waves, islanding a few last figures in distant pool!" (173) Attridge claims that in this scene "visionary and material, heaven and earth, sea and land, process and statis merge, and interact the conjoining of opposites extends and momentarily fulfill Stephen's intense experience on the beach, which like the earlier elevated moments, is quickly followed by its opposite" (Companion to Joyce 108). He maintains that this pattern of contrasts is repeated at various junctures in the narrative and that Joyce by juxtaposing extremes arranges the events of Stephen's life without relying on continuous narrative.

In chapter five Stephen in his esthetic conversation with Lynch asserts that he rejects didactic and pornographic arts and all the "kinetic" feelings which engage desire, but his own actions as well as his villanelle are in paradoxical opposition with his theoretical theories since they are within sexual realm. When in this conversation Stephen informs his friend of his esthetic theory of art and his definition of the pursuit of beauty, they suddenly see a "sizable hospital nurse" (Joyce 248), during their discussion they are passing a hospital, and deviate from their artistic discussion to pursue her; thus their pursuit of artistic beauty becomes the pursuit of sensual beauty. Therefore, the principles of Aquinas are forgotten and the speakers' "kinetic" feelings cause them to pursue their sensuous desires, which is, indeed, a paradoxical occurrence. Also Stephen's villanelle, as mentioned earlier, has totally a sensual nature because in this poem the naked body of the "temptress," "enfolded him like a shining cloud, enfolded him like water with a liquid life" (233); this fact is a paradoxical clash with his rejection of "kinetic" feelings as well as pornography. Regarding this point Splitter claims that "at least in his [Stephen's] imagination, in the act of writing- means surrendering to his physical desires, as he previously surrendered himself to a prostitute"' (196). Besides this, earlier in the novel in the same chapter under the library canopy Stephen feels the sensuous presence of his beloved and all the theories that he has gained from reading of Aquinas, Aristotle and other intellectual writers lap away from his mind and he gets delved in restlessness. This is another testimony that "[t]here is discrepancy between his impersonal aesthetic theory and his very personal poetic taste" (Singer 479).

The paradoxes and juxtapositions mentioned above are the significant ones which can be testified by the reader. However, among the most important juxtapositions of the novel one can also point to Stephen's fluctuation between the vertical axis of Catholicism and the horizontal axis of Bataille's "base materialism." He has been born in a strict Catholic order and has attended a religious educational system; then suddenly he turns toward luxurious orgiastic affairs with the whores. This conversion to the earthly affairs alternates directly with his changing direction toward religion, divinity, and heavenly bodies. After this conversion the reader witnesses again the beginning of Stephen's unrests which lead to his second rejection of Christianity and his also second conversion to mortal beauty and art which, as he himself confesses, must accompany with committing sin and fall "[o]n and on and on and on!" (Joyce 172), conveying 
endless repetition within the narrative of his life. These are the instances of juxtapositions, which Bataille affirms because they shatter the linearity of narrative and by creating voids and fissures within language make it a Bataillean headless labyrinth, which can never be controlled and solved.

\subsection{Silence, Ellipsis, and Transgression of Language}

Other devices which Georges Bataille claims can rupture the linearity of narrative structure are ellipsis and silence. These two words are of transcendental significance for Bataille because they have the impulsive energy to shatter and behead grammatical syntax as well as any narrative-the-head. As Bergson confirms syntax binds to the homogeneous time and that the syntactic succession of sentences and words will freeze the mobility and the fluidity of the linguistic being. In A Portrait Stephen's mind-the-stage is elliptical; these ellipses are voids and gaps which can never be filled by the vertical axis of narrative, syntax, and dictionary meanings. They are Bataillean "Impossible[s]" which are never fully materialized, but which one must move toward and must try to get closer and closer to. These ellipses, as Bataille claims, are heterogeneous spaces as they rupture the homogeneous system of language and narrative, and thus linear space and time, and that they sacrifice and mutilate violently this homogeneity forever. For Bataille, they are some voids and gaps which make language slippery; they create discontinuity within language and remove its coherence and thus its linearity. He also believes that ellipses disillusion the hallucinatory ideal of some final and ultimate unity. They cause the deferral of the center of every narrative; thus narrative becomes a decentered maze with no head ruling over it.

As mentioned, Stephen's linguistic mind is replete with these ellipses and abysses. The first instance of this ellipsis can be obviously observed in the first few pages of the novel when Stephen as a child is thinking about the ghost of a murderer and is enriching this thought with the color of his imagination followed immediately by his realistic saying his prayers to God: "Visit, we beseech Thee, O Lord, this habitation and drive away from it all..." (20). In the same page when he is on the train moving toward the home for the holidays and he is thinking of his father's house and its decoration for Christmas, his thoughts are cut by an ellipsis: "[t]here red holly and green ivy for him and for Christmas. / Lovely..." (20). When his family welcome him home "Welcome home, Stephen! / Noises..." (21). These ellipses are repeated over and over in the following pages of the novel. In the third chapter when he is so anguished of the thought of confession, he imagines his would-be-confessing sentences to the priest "-Father, I..." (126). Also, in his vision of the goatish creatures in this chapter he describes them as ones with "soft language issuing from their lips, their long swishing tails besmeared with stale shite, thrusting upwards their terrific faces..." (138). The scenes before and after his experiencing the epiphany of the mythological Daedalus are also full of elliptical sentences. After he experiences this moment his eyes are full of ecstasy and flight and his breath is wild: "- One! Two! ... Look out! / - oh, Cripes, I'm drowned! / - One! Two! Three and away! -The next! The next! -One! ... Uk!" (169) The last ellipsis of the book is in his diary in the last few pages of the novel when he is speaking of seeing her beloved: "all that I thought I thought and all that I felt I felt, all the rest before now, in fact.... O, give it up, old chap! Sleep it off!" (252) One must add this fact that the rupturing and sudden beginnings and cuttings of the expressed occurrences in Stephen's diary in the last pages of the novel can be regarded as disrupting ellipses which cut the continuity of the diary. These diary entries, as mentioned in this chapter, are cut abruptly and these abruptions convey the presence of ellipsis and silence which imply the existence of ambiguity and darkness forever. As Anthony Burgess asserts "the diary entries 'anticipate,' in their clipped lyricism and impatient ellipsis, the interior monologue of Ulysses" (qtd. In Levenson 1018). These ellipses are Bataillean heterological and horizontal voids which transgress the verticality of the narrative, and the energies of which are irruptive when they are released.

Another device praised by Georges Bataille because of its rich potentiality for creating violent and heterogeneous ruptures within the linear narrative is silence. Silence is a dark realm which cannot be illuminated and enlightened within the authoritative language system; it is what Bataille regards as a way to make language a headless labyrinth. Silence abolishes the linear narrative as well as the linear time. Linear narrative with its syntactical structure of sentences and words is very identical to the Bataillean Obelisk in that it is a vertical system which is looking upward in an ideal manner with the priority of utilitarian results which are, indeed, their endings. Silence is a factor appreciated so much by Bataille. For him, silence is a "blind spot" within the vertical narrative; this spot is blind forever and is deprived of any illuminating concept. Silence is an underlying violent and guillotine-like flux under the vertical frame of narrative. It is a tomb with no corpse within and thus with no definition; it is there forever, mute and dumb. No one can decipher silence because silence is everlastingly silent.

In $A$ Portrait the reader observes the existence of silence for many times which, as noted, remains untouchable forever. In the second chapter when Stephen's unrests and his wandering feelings have started the word "silence" with its variations are witnessed. Here he is pursuing an image eluding him and he hopes that he and this image will meet each other in a secret place and that "[t]hey would be alone, surrounded by darkness and silence" (65). The exact description and interpretation of this silence is impossible because silence is a dark realm of unknown. When Stephen meets his relatives with his mother "his mood of embittered silence did not leave him" (67). The most vital presence of not the word "silence" but the phenomenon of silence itself is when Stephen in the last page of the second chapter of the novel surrenders himself totally to a prostitute for the first time: "[t]hey [the prostitute's lips] pressed upon his brain as upon his lips as though they were the vehicle of a vague speech, and between them he felt an unknown and timid pressure, darker than the swoon of sin, softer than sound or odour" (101), the rest is silence. The reader can never know anything about the details of this love affair; a halo of silence, darkness, and unknown has embraced them. The system of language and narrative in this scene are mute forever. Here the dumb silence has created a big void which can never be decoded or even expressed by any vertical system. 
The reader can also observe the existence of silence in the following parts of the novel. Before and after the epiphany scene of the beach there exist some silences in the book: "[h]e heard confused music within him as of memories and names which he was almost conscious of but could not capture even for an instant; then the music seemed to recede, to recede, to recede, and from each receding trail of nebulous music there fell, always one long-drawn calling note, piercing like a star the dusk of silence" (168). After the epiphany the girl's image "had passed into his soul [for ever] and no word had broken the holy silence of his ecstasy" (172). He sleeps after experiencing an ecstasy in this scene on a bed of sand and grass; his sleeping implies a big silence here, and thus it implies a big gap within the narrative of his mind as well as of the book. Besides this, Stephen's sleeping conveys the dissolution of time and place. After his waking up and his describing the present atmosphere in a poetical and rhythmic language, the rest is again silence. Besides these explicit silences one can claim that the presence of the ellipses present in the novel can also be interpreted as implicit silences, because ellipses are everlasting dark and silent gaps within the narrative.

\subsection{Stephen's Language after the Beach Epiphany}

After his second conversion to mortal beauty at the beach epiphany, it is the disorder and the misrule of poetic sentences which pleases Stephen, not the exact order of any vertical structure. It is after this violent conversion from Christianity to earthly beauty that he inclines toward the artistic realm, and thereafter he plays on words as on the strings of a delicate musical instrument. It is here that he as a would-be-artist listens intently and consciously to the sounds of the words and is delved in a world of word sensation. In the homogeneous language net in which he has been entrapped from his birth words have become "emptied of instantaneous sense until every mean shop legend bound his mind like the words of a spell and his soul shriveled up sighing with age as he walked on in a lane of dead language" (178) Stephen is still moving in a world of conventional language and he has become aware of the insufficiency of this language: "he found himself glancing from one word to another on his right or left in stolid wonder that they had been so silently emptied of instantaneous sense" (178).

The accepted forms of expression no longer represent life for Stephen fully. He wants to impose on words of common currency a fresh and stronger light thus in the beach-epiphany scene he expresses his lyrical experience in a figurative and a non-utilitarian language:

His soul was swooning into some new world, fantastic, dim, uncertain as under sea, traversed by cloudy shapes and beings. A world, a glimmer or a flower? Glimmering and trembling, trembling and unfolding, a breaking light, an opening flower, it spread in endless succession to itself, breaking in full crimson and unfolding and fading to palest rose, leaf by leaf wave of life, flooding all the heavens with its soft flushes, every flush deeper than the other. (173)

After this sexual epiphany and his inclination to the realm of mortal art, his language exits from the common forms of the market and becomes complex and difficult. It becomes the scene of the random play of signifiers and is getting far from the hallucinatory signifieds:

His thinking was a dusk of doubt and self-mistrust, lit up at moments by the lightnings of intuition, but lightnings of so clear a splendor that in those moments the world perished about his feet as if it had been fire-consumed; and thereafter his tongue grew heavy and he met the eyes of others with unanswering eye, for he felt that the spirit of beauty had folded him round like a mantle and that in revery at least he had been acquainted with nobility. (176)

These rand plays signifiers continues in Stephen's psyche and his words "set to ban and disband themselves in wayward rhythms"; The Bataillean "jeu" of headless and Acephalic-like signifiers continues to the extent that his language dissolves in poetry: "The ivy whines upon the wall,/ And whines and twines upon the wall,/ The yellow ivy upon the wall,/ Ivy, ivy up the wall" (178). This is what Georges Bataille appreciates so much: when the normal language is merged in poetical one and the utility of the common words disappears. It is here that they become heterogeneous elements and can fill the voids of language momentarily. Bataille's own language in his works dissolves in poetical and mystical language; it follows the traumatic language of his own Critical Dictionary, in which words are totally beheaded.

As noted earlier, Stephen's epiphany experience at the beach has a sexual nature, because although he has no sexual affair with the girl in this scene, his depiction of her is completely sexual and full of sensual language; when he flights over the earth's backbone toward the "river's mouth"; the hard "spine of rocks" and again the fluid "river's mouth," all of which are erotic images. Indeed his sexual life is interrelated to his use of revivalist language, a language which uses figurative language, because after this epiphany experience his language, as mentioned, becomes totally complex. His language becomes phyzicalized and rhythmic:

Toward dawn he awoke. O what sweet music! His soul was all dewy wet. Over his limbs in sleep pale cool waves of light had passed. He lay still, as if his soul lay amid cool waters, conscious of 
faint sweet music. His mind was waking slowly to a tremulous morning knowledge, a morning inspiration. A spirit filled him, pure as the purest water, sweet as dew, moving as music.... His soul was waking slowly fearing to awake wholly. (216)

This physicalized language turns sharply toward verse and it becomes ambiguous and rhythmic, culmination of which is in Stephen's epiphanic moments of composing of the villanelle.

In composing the villanelle, after Stephen composes the first stanza the "verses passed from his mind to his lips and murmuring them over, he felt the rhythmic movement of a villanelle pass through them" (217). Here language is murmuring again and the dissolution of narrative, time and place is perceived. The act of this literary creation "emphasizes the workings of language as performed by decentralized, autonomous organs, as Stephen's lips are frequently said to murmur the verses" (Jacabos 31). In fact, before and after composing this villanelle, which is an impassioned poem, the language through which Stephen experiences linguistic limits is very complex and full of uncontrollable lyrical elements. Here his words do not mean what they are and they become completely figurative and, as mentioned, this "figurative language, [is a] language that by its very nature can never be controlled or brought to resolution through recourse to the 'rules' of grammar or syntax" (McDonald 374). The full text of this poem, composed directly after Stephen's literary-sexual epiphany at the beach, is his attempt to represent the 'liquid letters of speech, [the] symbols of the element of mystery (Jacobos 32). Here the recurrence of the words, images, and metaphors do not suggest a single unified meaning, but imply "delineate an ambivalent field of contradictory, conflicting desires" (Splitter 190). This villanelle represents the "dangerous, dirty, or life-giving stream of water, bodily fluids, or even words" (Joyce 194) which behead the grammatical syntax and semantic of the narrative and language. The instantaneous moment of the creation of this artistic piece is a Bataillean "consumptive" moment since he consumes the marketplace words and their utility excessively and produces a non-utilitarian piece of poem. It is a "non-productive expenditure" miraculous instant since it obeys no linear "profane project" with its prediction of result; it is an end in itself and is not for an end. This creative moment takes place by Bataille's appreciated "chance" and it follows no cause and effect.

Stephen as a character and a signifier in the book is in the process of Heraclitean flux of 'everchanging forms'" (Beplate 299). He is a signifier with no signified and is oozing and slipping within the narrative; he cannot be defined anymore neither by the surrounding discourses nor by the narrative of the book. He tries to transform through art the language, and thus the identity the world has imposed upon him; he is willing to be a creator, not a creature. His story of growing up and being entrapped within the existent language system and narrative and their big words becomes the story of his wrestling with this system. Stephen unmasks the ideal form the face of God and any other platonic idea by his "non servium" in act and in thought. He dismisses beauty as the reflection of another world and thus dismisses Plato and his world of Ideas. His escape from the entrapments of narrative and history is possible (not forever, of course) because he has the power of imagination and through this power he can create his own language; he himself has a story to tell as an artist. Stephen is a Luciferian character in the novel being courageous enough to rebel against his surrounding dominant discourses as well as the narrative and the system of language. He wants to be the creator of something which is timeless and, therefore, evades the brutal succession of cause and effect. Particularly after his conversion to earthly beauty his major attempt is to eschew the language of market as well as the imposed homogeneous language, literature, and custom, and it is for this reason that he wishes to abandon the finite order.

As noted earlier, Bataille believes that language system must be regarded as a headless labyrinth, which can never be solved, and that it has no entrance and no exit, therefore one cannot escape from it. It is a net which has entrapped the linguistic beings forever; a net full of voids and gaps. These voids make beings relational, and the existence of this relationality makes impossible the fulfillment of totality. Stephen Dedalus in A Portrait experiences some of these gaps momentarily through his transgressions, the gaps repressed by the vertical systems; however, he as a relational linguistic being cannot be a Bataillean "autonomous being" because the absolute and the total experience of these voids and fissures is impossible. As mentioned earlier, the taboos (which suffocate these voids) are always there even when transgressed, and their rooted presence prohibits Stephen from absolute transgression, and thus from absolute experience of these obscene gaps. This fact prohibits him from being a Bataillean "autonomous being." However, Georges Bataille believes that one must move toward this impossible "autonomous being" by experiencing the relational voids within language-the-labyrinth. Therefore, Stephen Dedalus, as a slippery signifier, must transgress the taboos and must experience the relational voids "[o]n and on and on and on" to get closer and closer to this Bataillean "Impossible" Therefore, one witnesses the lack of any closure and any signified upon this signifier; he is like the "eye" in Bataille's novel Story of the Eye which can never be defined, and whose serialized presence in the novel tolerates no determined meaning. As a slippery signifier Stephen, too, is doomed to slip in the relativity of language forever without reaching Bataille's state of being an "autonomous being" with a fix signified. Stephen-the-signifier abandons narrative very momentarily, but he is entrapped in the play of signifiers of language forever and will never have any fix sojourn.

Stephen Dedalus's transgression against his own self and the body of the Catholic society. As mentioned, consists moments of transgressing the erotic taboo and the repetition of these transgressions at the end of the second chapter and at the beginning of the third chapter of the novel are the origins of his transgression against his own self and the Catholic system. Before these moments, although Stephen is wandering throughout the obscene and infamous districts of Dublin and is appeased by "the fierce longings of his heart" (99) over and over, he does not cross any limits in deed. It is when he crosses the taboo of sex that he at the same time transgresses the boundaries of religion, society as well as his own self. In fact, his transgression is not only the transgression of the self and Catholicism, but also the 
transgression of his linguistic being as well as the whole system of language and narrative which encode and inscribe the body and the self. Language and world are so interrelated and interwoven with each other that one for the other one can be easily confused and, therefore, the transgression of the boundaries of the world is the transgression of the boundaries of language. Human beings are entrapped within the frame of language, and the linguistic narratives of language define them. Beings are empty voids without language and its narratives; they are vacuums without any meaning and nature. It is language which has entrapped the beings within its own web and defines the being of the beings. Human beings are the subjects of the conventional linguistic system of meaning and signification, and since, as mentioned, linguistic systems and the world are interrelated, to be subject in this system means "to be subjected to civilized economies, and these various economies insistently 'organize themselves as an homogeneous, unified front,' and narrow the space for 'social, sexual, or linguistic difference"' (Thomas 283).

\section{References}

Attridge, Derek. (2004a). Joyce's Effects on Language, Theory and History. Cambridge: Cambridge University Press. ed. (2004b).The Cambridge Companion to James Joyce. New York: Cambridge University Press.

Bataille, Georges. (1991). The Accursed Share. Trans. Robert Hurley.3 vols. New York: Zone Books.

--- (1962) Death and Sensuality: A Study of Eroticism and the Taboo. New York: Walker and Company.

Bruce Boone. (Trans). (1992). On Nietzsche. London: The Athlone Press.

Joachim Neugroschel (Trans). (1987). Story of the Eye.Trans. Joachim Neugroschel. San Francisco: City lights Books.

Theory of Religion.(1989). Trans. Robert Hurley. New York: Zone Books.

Benstock, Shari. (1982) "The Dynamics of Narrative Performance: Stephen Dedalus as Storyteller." ELH, Vol. 49, No.

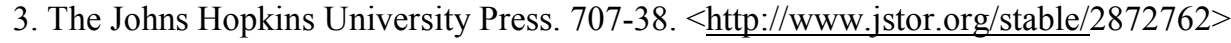

Beplate, Justin. (2005 ) "Joyce, Bergson, and the Memory of Words." The Modern Language Review, Vol.

100, No. 2.Modern Humanities Research Association. 298-312. <http://www.jstor.org/Stable/3737598>

Besnier, Jean-Michel, and Amy Reid. (1990) "Georges Bataille in 1930s: A Politics of the Impossible." Yale French Studies, No. 78.Yale University Press. 169-180. <http://www/jstor.org/stable/2930121>

Booker. M. Keith, and DubravkaJuraga. (1993) "Power and Oppression in Stalinist Russia and Catholic Ireland: DaniloKis'sUse of Joyce in 'A Tomb for Boris Davidovich."' South Atlantic Review, Vol. 58, No. 4. South Atlantic Modern Language Association.39-58. < http://www. jstor.org/stable/3201006>

Boulter, Jonathan. (2000) "The Negative Way of Trauma: Georges Bataille'sStory of the Eye." Cultural Critique, No. 46.University of Minnesota Press. 153-78. <http://www.jstor.org/stable/1354412>

Bourges, Antony. (1973). Language of James Joyce. New York: A Harvest/HBJ books.

Brenkman, John. (1979) "Introduction to Bataille."New German Critique, No. 16. Duke University Press. $59-63$. $<$ http://www.jstor.org/stable/487876>

Brown, Richard. (1985) James Joyce and Sexuality. New York: Cambridge University Press Us.

Bulson, Eric. (2006). The Cambridge Introduction to James Joyce. New York: Cambridge University Press.

Buttigieg, Joseph A. (1981). "The Struggle against Meta (Phantasma)-Physics: Nietzsche, Joyce and the Excess of History." Boundary 2, Vol. 9/10, No. 3. Duke University Press. 187-207. $<$ http://www.jstor.org/stable/303120>

Carroll, Michael P. (1995). "Rethinking Popular Catholicism in Pre-Famine Ireland."Journal for the Scientific Study of Religion, Vol. 34, No. 3.Blackwell Publishing.<http://www.jstor.org/ stable/1386884>

Conner, Peter. (1993). "Mysticism and Morality in Georges Bataille."Assemblage, No. 20. The MIT Press, $30-31$. http://www.jstor.org/stable/3181685

Crowly, Martin.(2004). "Bataille's Tacky Touch."MLN, Vol. 119, No. 4. The Johns Hopkins University Press. 766-80. $<$ http://www.jstor.org/stable/3251957>

Delmonico, Neal. (1973)."From Rapture to the AcéphalicMan: A Reading of Georges Bataille." Mississippi Review, Vol. 17, No. 1/2. University of Southern Mississippi. 49-71. <http://www.jstor.org/stable/20134191>

Deming, Robert H., ed. (2002). The Critical Heritage James Joyce.Vol. 1. New York: Routledge.

Valente, Joseph. (1989). Joyce and Sexuality. Cambridge: Cambridge University Press.

Doherty, James. (1963). "Joyce and Hell Opened to Christians: The Edition He Used for 'Hell Sermon."'Modern Philology, Vol. 61, No. 2. The University of Chicago Press.110-19. <http://www.Jstor.org/stable/435500>

Donoghue, Denis. (1960). "Joyce and the Finite Order."The Sewanee Review, Vol. 68, No. 2. The Johns Hopkins University Press. 31-48. <http://www.jstor.org/stable/435500>

Dragon, Dean. (1996). "The Work of Alterity: Bataille and Lacan."Diacritics, Vol. 26, No. 2. Baltimore: The Johns Hopkins University Press. 31-48. 
Elbarbary, Samir. (1989). "The Image of Goat in Portrait of the Artist as a Young Man."College Literature, Vol. 16, No. 3. College Literature. 261-73. <http://www.jstor.org/stable/25111827>

Fargnoli, A. Nicholas, and Michael Patrick Gillespie.(2006). A Critical Companion to James Joyce. NewYork: Facts On File, Inc.

Foster, John Wilson, ed. (2006) The Cambridge Companion to the Irish Novel. Cambridge: Cambridge University Press.

Gibson, Andrew. (2006). James Joyce. London: Reaktion Books Ltd.

Giovanelli, Felix, Stanislaus Joyce. (1950). "James Joyce: A Memoir." The Hudson Review. The Hudson Review, Inc. 485-514. <http://www.jstor.org/stable/3847704>

Goodwin, James. (2000). "Eisenstein, Ecstasy, Joyce and Hebraism."Critical Inquiry, Vol. 26, No. 3. The University of Chicago Press. 529-57. <http://www.jstor.org/stable/1344293>

Guerlac, Suzanne. (1996). "Bataille in Theory: Afterimage (Lascaux)." Diacritics, Vol. 26, No. 2.The Johns Hopkins University Press. 6-17. <http://www.jstor.org/stable/1566293>

Hayman, David. (1995). "Attitudinal Dynamics in Narrative: Flaubert, Lawrence, Joyce." Journal of ModernLiterature, Vol. 19, No. 2.Indiana University Press. 201-14. <http://www.jstor.org/stable/ 3831588>

---. (1985). "James Joyce, Paratactitian. "Contemporary Literature, Vol. 26, No. 2. University of Wisconsin Press. 15578. <http://www.jstor.org/stable/1207931>

Helming, Steven. (1988). "Joyce: Autobiography, History, Narrative." The Kenyon Review, New Series. Vol. 10 , No. 2.Kenyon College. 91-109. < http://www.jstor.org/stable/4335939>

Hollywood, Amy. (1999). "'Beautiful as a Wasp': Angela of Foligno and Georges Bataille." The Harward Theological Review, Vol. 92, No. 2. Cambridge University Press. 219-36.<http://www.jstor.org/stable/1510055>

---. (1996). "Bataille and Mysticism: A 'Dazzling Dissolution."' Diacritics, Vol. 26, No. 2. Baltimore: The Johns Hopkins University Press. 74-85.

Irwin, Alexander. (2002). Saints of the Impossible: Bataille, Weil, and the Politics of the Sacred. London: University of Minnesota Press.

Itzkowit, Kenneth. (1999). "To Witness Spectacles of Pain: The Hypermorality of Georges Bataille." College Literature, Vol. 26, No. 1. College Literature. 19-33. <http://www.jstor.org/stable/25112426>

Jacobs, Joshua. (2000). "Joyce's Epiphanic Mode: Material Language and the Representation of Sexuality in Stephen Hero and Portrait." Twentieth Century Literature, Vol. 46. No. 1.Hofstra University. $22-33$. $<\mathrm{http}$ ://www.jstor.org/stable/441931>

Joyce, James. (2011). A Portrait of the Artist as Young Man. London: Urban Romantics.

Jurga, Dubravka, M. Keith Booker. (1993). "Literature, Power, and Oppression in Stalinist Russia and Catholic Ireland: DaniloKis's Use of Joyce in A Tomb for Boris Davidovich." South AtlanticReview, Vol. 58, No. 4. South Atlantic Modern Language Association. 39-58.<http://www.jstor.org/stable/3201006>

Kaufman, Eleanor. (2001). The Delirium of Praise: Bataille, Blanchot, Deleuze, Foucault, Klossowski.Baltimore: The Johns Hopkins University Press.

Kendall, Staurt. (2007). Georges Bataille. London: Reaktion Books Ltd.

Kershner, R. B. (1986). "The Artist as Text: Diologism and Incremental Repetition in Joyce's Portrait." ELH, Vol. 53, No. 4. The Johns Hopkins University Press. 881-94.<http://www.jstor.org/stable/2873178>

Kibler, Louis. (1974). "Imagery in Georges Bataille'sLe Bleu du ciel."The French Review. Special Issue, No. 6. California: American Association of Teachers of French. 208-18.

Kosky, Jeffrey. (2004). "Georges Bataille's Religion without Religion: A Review of the Possibilities Opened by The Publication of The Unfinished System of Knowledge." The Journal of Religion, Vol. 84, No. 1. The University of Chicago Press. 78-87. <http://www.jstor.org/stable/10.1086/512691>

Lahiji, Nadir. (1996). "The Gift of the Open Hand: Le Corbusier Reading Georges Bataille'sLa Part Maudite.Maudite."Journal of Architectural Education, Vol. 50, No. 1.Blackwell Publishing. $50-76$. $<$ http://www.jstor.org/stable/1425620>

Lala, Maria-Christine, and Robert Livingston.(1990). "The Conversions of Writing in Georges Bataille'sL'Impossible."Yale French Studies, No. 78. Connecticut: Yale University Press. 23745.<http://www.jstor.org/stable/2930125>

Lechte, John. (2001). Fifty Key Contemporary Thinkers: from Structuralism to Postmodernity. New York:Routledge.

Leonard, Garry.(1995). "The City, Modernism, and Aesthetic Theory in A Portrait of the Artist as a YoungMan."NOVEL: A Forum on Fiction, Vol. 29, No. 1. Carolina: Duke University Press. 7999.<http://www.jstor.org/stable/1345541> 
Levenson, Michael. (1985). "Stephen's Diary in Joyce's Portrait-The Shape of Life."ELH, Vol. 52, No. 4. The Johns Hopkins University Press. 1017-35. <http://www.jstor.org/stable/3039476>

Libertson, Joseph. (1976). "Proximity and the Word: Blanchot and Bataille." Substance, Vol. 5, No. 14.University of Wisconsin Press. 35-49. <http://www.jstor.org/stable/3684293>

---. (1977). "Excess and imminence: Transgression in Bataille." NLN, Vol. 92, No. 5. The Johns HopkinsUniversity Press. 1001-23. <http://www.jstor.org/stable/2906888>

Lowe-Evans, Mary. (1990). "Sex and Confession in the Joyce Canon: Some Historical Parallels."Journal of Modern Literature, Vol. 16, No. 4.Indiana University Press. 563-76. <http://www.jstor.org/Stable/3831419>

McCarthy, Michael J. F. (1902). Priest and People in Ireland. Dublin: Hodges, Figgis\&co.

Martin, Timothy P. (1984). "Joyce, Wagner, and the Artist-Hero."Journal of Modern Literature, Vol. 11, No. 1.India University Press. 66-88. <http://www.jstor.org/stable/3831154>

Mason, Ellsworth. (1956). "James Joyce: Moralist." Twentieth Century Literature, Vol. 1, No. 4. Hofstra University. 196-206. <http://www.jstor.org/stable/440909>

McCabe, Colin. (2003). James Joyce and the Revolution of the Word. New York: Polgrave MacMillan.

McCourt, John. (2009). James Joyce in Context. Cambridge: Cambridge University Press.

McDonald, Michael Bruce. (1991). "The Strength and Sorrow of Young Stephen: Toward a Reading of the Dialectic of Harmony and Dissonance in Joyce's Portrait." Twentieth Century Literature, Vol. 37, No. 4. New York: Hofstra University. 361-89. <http://www.jstor.org/stable/441652>

McMichael, James . (1989). "James Joyce Speaks." The Kenyon Review, New Series, Vol. 11, No. 3. KenyonCollege. 27-40. http://www.jstor.org/stable/4336103

Michelson, Annette. (1986). "Heterology and the Critique of Instrumental Reason."October, Vol. 36. Massachusetts: The MIT Press. 111-27. <http://www.jstor.org/stable/778559>

Milesi, Laurent, ed. (2003). James Joyce and the Difference of Language. Cambridge: Cambridge University Press.

Morse, J. Mitchell. (1957). "The Disobedient Artist: Joyce and Loyola." PMLA, Vol. 72, No. 5. Modern Language Association. 1018-35. < http://www.jstor.org/stable/460377>

Nicholson, Melanie. (1999). "Pizarnik, Aljandra, Georges Bataille and the Literature of Evil."Latin AmericanLiterary Review, Vol. 27, No. 54. Latin American literary Review. 5-22. <http://www.jstor org/stable/20119809>

Noys, Benjamin. (2000). Georges Bataille: A Critical Bataille Introduction. London: Pluto Press.

Pollock, Michele R. (1973). "Georges Bataille: Literature and Sovereignty." SubStance, Vol. 3, No. 7.University of Wisconsin Press. 49-71. http://www.jstor.org/stable/3684587

Power, Arthur. (1999). Conversations with James Joyce. Dublin: Lilliput Press.

Prescott, Joseph. (1939). "James Joyce: A Study in Words." PMLA, Vol. 54, No. 1. Modern LanguageAssociation. 30415. $<$ http://www.jstor.org/stable/458640>

Reid, B. L. (1984). "Gnomon and Order in Joyce's Portrait." The Sewanee Review, Vol. 2, No. 3. The Johns Hopkins University Press. 397-420. <http://www.jstor.org/stable/27544312>

Reynold, Mary T. (1976). "Joyce's Villanelle and D'Annunzio's Sonnet Sequence."Journal of Modern Literature, Vol. 5, No. 1.Indiana University Press. 19-45. <http://www.jstor.org/stable/3830953>

Ryf, Robert S. (1964). A New Approach to Joyce The Portrait of the Artist as Guide Book. Los Angeles: University of California Press.

Schwarze, Tracey Teets. (1997). "Silencing Stephen: Colonial Pathologies in Victorian Dublin." Twentieth Century Literature.Hofstra University. 243-63. <http://www.jstor.org/stable/441911>

Scholes, Robert. (1964). "Joyce and Epiphany: The Key to the Labyrinth." The Sewanee Review, Vol. 72, No.1. The Johns Hopkins University Press. 65-77. < http://www.jstor.org/stable/27540956>

Singer, Thomas C. (1990). "Riddles, Silence, and Wonder: Joyce and Wittgenstein Encountering the Limits ofLanguage."ELH, Vol. 57, No. 2. The Johns Hopkins University Press. $<\mathrm{http} / / / w w w . j s t o r . o r g / 2873080>$

Splitter, Randolph. (1982). "Watery Words: Language, Sexuality, and Motherhood in Joyce's Fiction." ELH, Vol. 49, No. 1. The Johns Hopkins University press. 190-213. <http://www.jstor.org/stable/2872888>

Spoo, Robert. (1988). "Joyce's Attitude toward History: Rome, 1906-07." Journal of Modern Literature, Vol. 14, No. 4.Indiana University Press. 481-97. < http://www.jstor.org/stable/3831561>

---. (1994). James Joyce and the Language of History: Dedalus's Nightmare. New York and Oxford: Oxford University Press.

Thomas, Calvin. (1990). "Stephen in Process/Stephen on Trial: The Anxiety of Production in Joyce's Portrait." NOVEL: A Forum on Fiction, Vol. 23, No. 3. Duke University Press: 282-302. <http://www.jstor.org/stable/1345954> 
Thrane, James R. (1960). "Joyce's Sermon on Hell: Its Source and Its Background." Modern Philology, Vol. 57, No. 3. The University of Chicago Press. 172-98. <http://www.jstor.org/stable/435138>

Toolan, Michael. (1987). "Analyzing Conversation in Fiction: The Christmas Dinner Scene in Joyce's Portrait of the Artist as a Young Man." Poetics Today, Vol. 8, No. 2. Carolina: Duke University Press. 398-416. $<$ http://www.jstor.org/stable/1773043>

Walzl, Florence L. (1965)."The Liturgy of the Epiphany Season and the Epiphanies of Joyce."PMLA, Vol.80, No. 4. Modern Language Association. 436-50. <http://www.jstor.org/stable/460937>

Weiss, Allen S. (1986). "Impossible Sovereignty: Between "The Will to Power" and "The Will to Chance."October, Vol. 36. Massachusetts: The MIT Press. <http://www.jstor.org/stable/778560>

Weston, Michael. (2001). Philosophy, Literature and the Human Good. New York: Routledge.

Wilde, Dana. (1989). "A Note on Stephen's Shapeless Thoughts from Swedenborg in A Portrait of the Artist."Journal of Modern Literature, Vol. 16, No. 1.Indiana University Press. 179-81. <http://www.jstor.org/stable/3831382> 